\title{
Production of polysaccharide and surfactin by Bacillus subtilis ATCC 6633 using rehydrated whey powder as the fermentation medium
}

\author{
A. Cagri-Mehmetoglu, ${ }^{1}{ }^{1}$ S. Kusakli, ${ }^{\star}$ and M. van de Venter† \\ ${ }^{*}$ Department of Food Engineering, Faculty of Engineering, Sakarya University, Sakarya, Turkey 54187 \\ †Department of Biochemistry and Microbiology, Faculty of Science, Nelson Mandela Metropolitan University, Port Elizabeth, 6031, South Africa
}

\begin{abstract}
The aim of this research was to assess the amounts of polysaccharide and surfactin produced by Bacillus subtilis ATCC 6633 in rehydrated whey powder (RWP) as the growth medium. One-day-old cultures of B. subtilis $(\sim 4.6 \log \mathrm{cfu} / \mathrm{mL})$ were inoculated into $100 \mathrm{~mL}$ of 10 , 15 , or $20 \%$ (wt/vol) RWP and incubated at $30^{\circ} \mathrm{C}$ for 72 $\mathrm{h}$. To analyze the effects of lactose and protein on polysaccharide and surfactin production, 6 RWP solutions containing different levels of lactose and protein were also used as media. The number of vegetative cells and spores, $\mathrm{pH}$, viscosity, and the concentration of lactose were determined at $0,24,48$, or $72 \mathrm{~h}$ of fermentation. The levels of polysaccharide and surfactin produced after $72 \mathrm{~h}$ of fermentation were measured using HPLC and the phenol-sulfuric acid method, respectively. During $72 \mathrm{~h}$ of fermentation, B. subtilis populations increased from 4.6 to $10.54,9.82$, and $9.67 \log _{10} \mathrm{cfu} / \mathrm{mL}$ in 10,15 , and $20 \%$ RWP, respectively. The number of B. subtilis spores in $10 \%$ RWP increased from 3.91 to $4.72 \log _{10}$ $\mathrm{cfu} / \mathrm{mL}$ after 48 and $72 \mathrm{~h}$ of fermentation, respectively. The increased level of lactose or protein in RWP did not significantly change the vegetative growth. After 72 $\mathrm{h}$ of fermentation, the $\mathrm{pH}$ of RWP decreased from 5.70 to 4.99 with a slight increase in viscosity. Polysaccharide levels in 10, 15, and 20\% RWP after fermentation were $513.6,613.5$, and $768.3 \mathrm{mg} / \mathrm{L}$, respectively, with B. subtilis producing 0.18 to $0.29 \mathrm{~g} / \mathrm{L}$ of surfactin after $72 \mathrm{~h}$ of fermentation. The polysaccharide or surfactin production was not changed significantly by addition of protein or lactose to RWP. These results indicate that RWP is a good fermentation substrate for surfactin and polysaccharide production.
\end{abstract}

Key words: whey powder solution, Bacillus subtilis, polysaccharide, surfactin

Received January 26, 2012.

Accepted March 4, 2012.

${ }^{1}$ Corresponding author: acagri@sakarya.edu.tr

\section{INTRODUCTION}

Extracellular polysaccharides (EPS) are produced by growth of many gram-negative and gram-positive bacteria (Wingender et al., 1999). They are bound to the cell surface and then released into solution. Microbial EPS offer a potential new source of functional biopolymers for food, industrial, and medical applications. These bacterial polysaccharides can be incorporated into food as thickeners, suspending agents, or gelling agents to improve food quality and texture (Stephens, 1995). Bacillus subtilis is also a bacterial source for the production of EPS and antibiotics by fermentation (Mitsuda et al., 1981; Desai and Banat, 1997). Some B. subtilis strains can produce surfactin, which is one of the most powerful biosurfactants and antimicrobials (Perez et al., 1992; Desai and Banat, 1997; Heerklotz and Seelig, 2001; Stein, 2005).

Whey, a by-product of the dairy industry, has received wide-reaching attention by researchers due to its high nutritional value and functional properties (Horton, 1993). Whey contains lactose $(4.9 \%$, wt/vol), protein $(0.8 \%$, wt $/ \mathrm{vol})$, lipid $(0.17 \%)$, and trace amounts of vitamins, minerals, and organic acids (Gulsun and Sahan, 1992). It has been investigated as a medium for the growth of various microorganisms (Feijoo et al., 1999; Lee et al., 1997; Yagci et al., 2006). The use of whey as a cheap fermentation substrate for production of polysaccharide, surfactant, enzymes, vitamins, or antibiotics would help to decrease whey disposal. Some studies have showed that whey permeate could be used as a fermentation substrate for Pseudomonas spp. or Klebsiella oxytoca to produce polysaccharides or rhamnolipid biosurfactant (Stauffer and Leeder, 1978; Dlamini and Peiris, 1997a,b; Rech et al., 1999; Kahyaoglu and Konar, 2006). However, we found no studies in the literature that investigated the growth of B. subtilis in whey or production of polysaccharides and surfactin by whey fermentation.

Consequently, our objectives were (1) to evaluate rehydrated whey powder as a fermentation substrate for the growth of $B$. subtilis, and (2) to assess the production of polysaccharide and surfactin using rehy- 
drated whey powder as the fermentation substrate for B. subtilis.

\section{MATERIALS AND METHODS}

\section{Culture Preparation}

Bacillus subtilis ATCC 6633 was obtained from the Health Department of Refik Saydam Hifzisiha (Ankara, Turkey). The culture was stored in tryptic soy broth (Difco Laboratories, Detroit, MI) containing 6\% yeast extract and glycerol at $-60^{\circ} \mathrm{C}$ until use. Two successive transfers $\left(30^{\circ} \mathrm{C}\right.$ for $\left.24 \mathrm{~h}\right)$ were prepared in $10 \mathrm{~mL}$ of tryptic soy broth (Difco Laboratories) using a $1 \%$ inoculum, after which the culture was pelleted by centrifugation $\left(12,000 \times g\right.$ for $30 \mathrm{~min}$ at $\left.4^{\circ} \mathrm{C}\right)$ and resuspended in sterile water for subsequent inoculation.

\section{Preparation and Inoculation of Rehydrated Whey Powder}

Rehydrated whey powder (RWP; 10, 15, and 20\% $\mathrm{wt} / \mathrm{vol}$ ) was prepared using whey powder composed of 83 to $85 \%$ lactose, 5.5 to $6.5 \%$ protein, $5.5 \%$ mineral, $2 \%$ moisture, and $0 \%$ fat obtained from a dairy plant (Milkon, Adapazari, Turkey). After RWP was autoclaved at $121^{\circ} \mathrm{C}$ for $15 \mathrm{~min}$ and cooled to room temperature $\left(24^{\circ} \mathrm{C}\right)$, one loop of the B. subtilis suspension was added into 100-mL aliquots of 10,15 , and $20 \%$ RWP, which were then incubated at $30^{\circ} \mathrm{C}$ for $72 \mathrm{~h}$. Uninoculated 10 , 15 , and $20 \%$ RWP were prepared as controls.

To determine the effect of protein or lactose concentration in RWP on growth and polysaccharide production of $B$. subtilis, 3 different protein and lactose concentrations of solutions were prepared using RWP. For this objective, RWP solution (20\%) was autoclaved for $15 \mathrm{~min}$ and centrifuged at $4,500 \times g$ at $4^{\circ} \mathrm{C}$ for 30 min. Supernatant and yeast extract (Difco Laboratories) were used to prepare solutions containing 2.5, 7.5, and $10.0 \%$ lactose and $0.5 \%$ protein in sterile distilled water. The pellet and lactose were used to prepare 0.5 , 1.0 , and $1.5 \%$ whey protein solutions containing $2.5 \%$ lactose. These solutions were inoculated with one loop of overnight B. subtilis culture and incubated for $72 \mathrm{~h}$ at $30^{\circ} \mathrm{C}$ in a shaker incubator.

\section{Bacterial Enumeration and Determination of the Number of Spores}

Vegetative cells of $B$. subtilis were quantified in RWP after 24,48 , and $72 \mathrm{~h}$ of fermentation at $30^{\circ} \mathrm{C}$. Serial dilutions prepared using $0.1 \%$ (wt/vol) peptone water were surface-plated on tryptic soy agar (Difco Labo- ratories) with the plates counted after 25 to $30 \mathrm{~h}$ of incubation at $30^{\circ} \mathrm{C}$.

Spore populations were determined in RWP after 24, 48 , and $72 \mathrm{~h}$ of fermentation at $30^{\circ} \mathrm{C}$ using the rope spore method (Halkman and Akcelik, 2000). Fermented RWP was placed in an $80^{\circ} \mathrm{C}$ water bath (M96 kpk, Elektro-mag, Mountain View, CA) for 20 min to kill vegetative cells and then cooled in an ice bath. Appropriate serial dilutions in $0.1 \%$ peptone water were then surface-plated on dextrose casein-peptone agar (Difco Laboratories), with the plates counted after $48 \mathrm{~h}$ of incubation at $37^{\circ} \mathrm{C}$.

\section{Determination of Viscosity and $\mathrm{pH}$ Measurement}

Viscosity of RWP was measured during the 72-h fermentation using a capillary Oswalt viscometer (Schott Gerate GmbH, Mainz, Germany). Fermented RWP (3 $\mathrm{mL}$ ) or distilled water was placed into the capillary tube of the viscometer and then the tube was placed in a $22^{\circ} \mathrm{C}$ water bath. After the RWP or distilled water reached line $\mathrm{A}$ in the capillary tube, the time for the fluid to flow to line B was recorded using a chronometer; this time interval was then used to calculate the viscosity.

The $\mathrm{pH}$ was recorded initially and at 24-h intervals during the 72-h fermentation using a pH meter (pH 211 meter, Hanna, Woonsocket, RI).

\section{Lactose Concentration}

The amount of lactose in fermented RWP was determined by infrared spectrometry using a MilkoScan FT-120 (Foss, Rellingen, Germany). Samples were prepared according to manufacturer's recommendation. Samples were diluted 5 times and readings were performed in the mid-infrared range with wavelengths from 3 to $10 \mu \mathrm{m}\left(1,000-5,000 \mathrm{~cm}^{-1}\right)$, and the spectra were exported and stored in electronic files. At least 5 independent spectra, each obtained by averaging 3 scans of a sample, were obtained per sample.

\section{Determination of Polysaccharide Concentration}

Bacillus subtilis was cultivated aerobically in RWP at $30^{\circ} \mathrm{C}$ and $150 \mathrm{rpm}$ (orbital shaker). The cells were harvested by centrifugation $\left(5,000 \times g, 30 \mathrm{~min}, 4^{\circ} \mathrm{C}\right)$ after which the supernatant solution was then centrifuged $\left(12,000 \times g, 30 \mathrm{~min}, 4^{\circ} \mathrm{C}\right)$ to remove residual cells. The EPS was precipitated from the supernatant by adding cold reagent-grade ethanol at a volumetric ratio of $3: 1$ and stored at $4^{\circ} \mathrm{C}$ for $24 \mathrm{~h}$ (de Brouwer et al., 2002). After centrifugation $\left(12,000 \times g, 30 \mathrm{~min}, 4^{\circ} \mathrm{C}\right)$, the pel- 
let was dissolved in distilled water and concentrated by ultrafiltration using a 30,000 molecular-weight-cutoff membrane (model 8010, Millipore Corp., Bedford, MA). The retentate was washed twice with deionized water, and finally the polysaccharide was dissolved in deionized water for $24 \mathrm{~h}$, freeze-dried, and stored at $-20^{\circ} \mathrm{C}$ pending analysis. Total carbohydrate levels were estimated using the phenol-sulfuric method (Hanson and Phillips, 1981). A purified form of a gellan gum (Gelzan, Sigma-Aldrich, St. Louis, MO) was used as the standard.

\section{Isolation of and Quantitative Analysis of Surfactin}

Crude surfactin was isolated by adding concentrated $\mathrm{HCl}$ to RWP after removing the biomass by centrifugation (Cooper et al., 1981). The precipitate that formed at $\mathrm{pH} 2$ was collected, dried, and extracted with dichloromethane. The solvent was removed under reduced pressure to yield an off-white solid. Further purification was achieved by recrystallization. The dichloromethane extract was dissolved in distilled water, adjusted to $\mathrm{pH}$ 7 with $\mathrm{NaOH}$, filtered through Whatman no. 4 paper, and then readjusted to $\mathrm{pH} 2$ with concentrated $\mathrm{HCl}$. The white solid was collected as a pellet after centrifugation.

The isolated surfactin pellet was dissolved in $1 \mathrm{~mL}$ of methanol followed by charcoal treatment and passed through a $0.22-\mu \mathrm{m}$-pore filter. The filtrate was subjected to HPLC on a reversed-phase column (RP-18, 5 $\mu \mathrm{m}, 4 \times 250 \mathrm{~mm}$; Merck and Co. Inc., Kelco Division, Sydney, Australia). The column was eluted at a flow rate of $1.0 \mathrm{~mL} / \mathrm{min}$ with acetonitrile-trifluoroacetic acid $(3.8 \mathrm{mM} ; 80: 20, \mathrm{vol} / \mathrm{vol})$ and monitored at $210 \mathrm{~nm}$. The concentration of surfactin was determined from a calibration curve made with surfactin purchased from Sigma.

\section{Statistical Analysis}

All experiments were replicated 3 times. Two-way ANOVA was performed using SAS software (SAS Institute, 1990). Means were compared using the Duncan grouping test at $P=0.05$.

\section{RESULTS}

Bacillus subtilis grew well during the fermentation of RWP. The population of vegetative cells in $10 \%$ RWP increased from 4.8 to 8.69 and $10.66 \log \mathrm{cfu} / \mathrm{mL}$ after 24 and $48 \mathrm{~h}$ at $30^{\circ} \mathrm{C}(P<0.05)$, respectively, and then declined by 0.11 logs after $72 \mathrm{~h}$ (Table 1). Similar growth of B. subtilis was also observed in 15 and $20 \%$ RWP, with numbers increasing 5.4 logs during the first $48 \mathrm{~h}$ of incubation and then declining by 0.7 to 0.8 logs. The growth of vegetative cells in nutrient broth only after $48 \mathrm{~h}$ of fermentation was significantly more than the growth in the RWP solutions $(P<0.05)$. However, different ratios of lactose and protein in the RWP solutions did not significantly affect vegetative growth $(P$ $<0.05)$.

After $72 \mathrm{~h}$ of fermentation, the B. subtilis spore count in 10,15 , and $20 \%$ RWP was $4.73,3.83$, and $3.69 \mathrm{cfu} /$ $\mathrm{mL}$, respectively (Table 2). The density of spores in nutrient broth was not significantly different from those in RWP solutions $(P<0.05)$. However, fewer than 1.3

Table 1. The density of vegetative cells $\left(\log _{10} \mathrm{cfu} / \mathrm{mL}\right)$ in 10,15 , or $20 \%$ rehydrated whey protein (RWP) and RWP containing different ratios of lactose and protein during $72 \mathrm{~h}$ of fermentation ${ }^{1}$

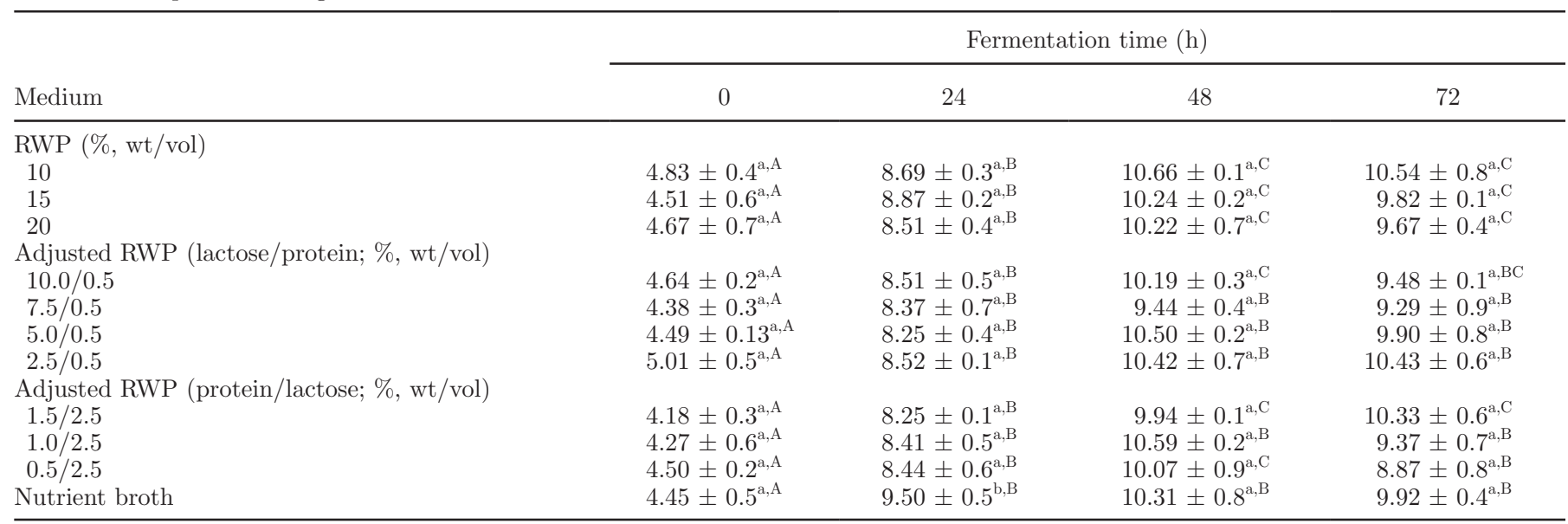

${ }^{\mathrm{a}, \mathrm{b}}$ Different lowercase letters within a column are significantly different $(P<0.05)$.

${ }^{\mathrm{A}-\mathrm{C}}$ Different uppercase letters within a row are significantly different $(P<0.05)$.

${ }^{1}$ Values are mean $\pm \mathrm{SD}(\mathrm{n}=3)$. 
Table 2. Bacillus subtilis spore populations $\left(\log _{10} \mathrm{cfu} / \mathrm{mL}\right)$ in 10,15 , or $20 \%$ rehydrated whey protein (RWP) and RWP containing different ratios of lactose and protein during $72 \mathrm{~h}$ of fermentation ${ }^{1}$

\begin{tabular}{|c|c|c|c|c|}
\hline Medium & 0 & 24 & 48 & 72 \\
\hline \multicolumn{5}{|l|}{ RWP (\%,wt/vol) } \\
\hline 10 & $<1.3 \pm 0.0^{\mathrm{a}, \mathrm{A}}$ & $2.53 \pm 0.5^{\mathrm{b}, \mathrm{B}}$ & $3.91 \pm 0.2^{\mathrm{b}, \mathrm{C}}$ & $4.73 \pm 0.1^{\mathrm{b}, \mathrm{D}}$ \\
\hline 15 & $<1.3 \pm 0.0^{\mathrm{a}, \mathrm{A}}$ & $2.65 \pm 0.3^{\mathrm{b}, \mathrm{B}}$ & $3.17 \pm 0.7^{\mathrm{b}, \mathrm{B}}$ & $3.85 \pm 0.2^{\mathrm{b}, \mathrm{B}}$ \\
\hline 20 & $<1.3 \pm 0.0^{\mathrm{a}, \mathrm{A}}$ & $2.31 \pm 0.4^{\mathrm{b}, \mathrm{B}}$ & $3.96 \pm 0.1^{\mathrm{b}, \mathrm{C}}$ & $3.69 \pm 0.1^{\mathrm{b}, \mathrm{C}}$ \\
\hline \multicolumn{5}{|c|}{ Adjusted RWP (lactose/protein; \%, wt/vol) } \\
\hline $5.0 / 0.5$ & $<1.3 \pm 0.0^{\mathrm{a}, \mathrm{A}}$ & $3.91 \pm 0.1^{\mathrm{c}, \mathrm{B}}$ & $3.16 \pm 0.02^{\mathrm{b}, \mathrm{B}}$ & $3.54 \pm 0.8^{\mathrm{b}, \mathrm{B}}$ \\
\hline $2.5 / 0.5$ & $<1.3 \pm 0.0^{\mathrm{a}, \mathrm{A}}$ & $3.47 \pm 0.7^{\mathrm{c}, \mathrm{B}}$ & $3.52 \pm 0.4^{\mathrm{b}, \mathrm{B}}$ & $4.75 \pm 0.7^{\mathrm{b}, \mathrm{C}}$ \\
\hline \multicolumn{5}{|c|}{ Adjusted RWP (protein/lactose; \%, wt/vol) } \\
\hline $1.5 / 2.5$ & $<1.3 \pm 0.0^{\mathrm{a}, \mathrm{A}}$ & $4.26 \pm 0.1^{\mathrm{d}, \mathrm{B}}$ & $4.52 \pm 0.2^{\mathrm{c}, \mathrm{B}}$ & $4.97 \pm 0.9^{\mathrm{b}, \mathrm{B}}$ \\
\hline $1.0 / 2.5$ & $<1.3 \pm 0.0^{\mathrm{a}, \mathrm{A}}$ & $4.03 \pm 0.8^{\mathrm{d}, \mathrm{B}}$ & $4.40 \pm 0.1^{\mathrm{c}, \mathrm{B}}$ & $4.85 \pm 1.2^{\mathrm{b}, \mathrm{B}}$ \\
\hline $0.5 / 2.5$ & $<1.3 \pm 0.0^{\mathrm{a}, \mathrm{A}}$ & $4.26 \pm 0.2^{\mathrm{d}, \mathrm{B}}$ & $4.33 \pm 0.6^{\mathrm{c}, \mathrm{B}}$ & $4.84 \pm 0.8^{\mathrm{b}, \mathrm{B}}$ \\
\hline Nutrient broth & $<1.3 \pm 0.0^{\mathrm{a}, \mathrm{A}}$ & $4.32 \pm 0.1^{\mathrm{d}, \mathrm{B}}$ & $4.99 \pm 0.5^{\mathrm{c}, \mathrm{B}}$ & $4.83 \pm 0.9^{\mathrm{b}, \mathrm{B}}$ \\
\hline
\end{tabular}

${ }^{\mathrm{a}-\mathrm{c}}$ Different lowercase letters within a column are significantly different $(P<0.05)$.

${ }^{\mathrm{A}-\mathrm{D}}$ Different uppercase letters within a row are significantly different $(P<0.05)$.

${ }^{1}$ Values are mean $\pm \mathrm{SD}(\mathrm{n}=3)$.

$\log _{10} \mathrm{cfu} / \mathrm{mL}$ spores were observed during $48 \mathrm{~h}$ of fermentation in RWP solution containing $10 \%$ lactose and $0.5 \%$ protein. The density of spores in the latter RWP solution was significantly less than in the other solutions used $(P<0.05)$.

Prior to inoculation, the $\mathrm{pH}$ of 10,15 , and $20 \%$ RWP was 5.75, 5.61, and 5.53, respectively (Figure 1a). After $72 \mathrm{~h}$ of incubation, the $\mathrm{pH}$ of 10,15 , and $20 \%$ RWP decreased significantly to 4.99, 4.99, and 5.21, respectively $(P<0.05)$. The significant decrease in $\mathrm{pH}$ was parallel to the significant growth of B. subtilis and subsequent lactic acid production from lactose. In fact, the correlation between $\mathrm{pH}$ and the amount of lactose was $80.9,99.6$, and $97.5 \%$ for 10,15 , and $20 \%$ RWP, respectively, during $72 \mathrm{~h}$ of $B$. subtilis fermentation.

The amount of lactose in 10\% RWP significantly decreased from 8.5 to $7.6 \%$ after $48 \mathrm{~h}$ of B. subtilis fermentation $(P<0.05$; Figure $1 \mathrm{~b})$ and then stabilized. In $15 \%$ RWP, lactose decreased from 12.75 to $10.95 \%$ after $24 \mathrm{~h}(P<0.05)$ of fermentation and remained unchanged thereafter. However, in $20 \%$ RWP, the level of lactose continued to decrease significantly from 17 to $14.15,13.6$, and $13.05 \%$ after $72 \mathrm{~h}$ of fermentation $(P$ $<0.05)$.

Viscosity of 10, 15, and 20\% RWP increased significantly from $2.1,2.9$, and $3.2 \mathrm{cP}$ to $2.9,3.5$, and $3.9 \mathrm{cP}$, respectively, after $72 \mathrm{~h}$ of fermentation with $B$. subtilis $(P<0.05$; Figure 1c). After $72 \mathrm{~h}$ of fermentation at $30^{\circ} \mathrm{C}$ with B. subtilis, 10,15 , and $20 \%$ RWP yielded $513.6,613.5$, and $768.3 \mathrm{mg} / \mathrm{L}$ of polysaccharides, respectively, with the increase in polysaccharide parallel to the increase in RWP concentration (Table 3; $P<$ $0.05)$. However, an increase in protein or lactose level in
RWP solution did not significantly change polysaccharide production by $B$. subtilis $(P<0.05)$. The production of polysaccharide by $B$. subtilis in nutrient broth was also not significantly different from that in RWP $(P<0.05)$.

After $72 \mathrm{~h}$ of fermentation at $30^{\circ} \mathrm{C}, 10,15$, and $20 \%$ RWP yielded, respectively, $0.23,0.18$, and $0.24 \mathrm{~g} / \mathrm{L}$ of surfactin (Table 3). The amount of surfactin produced by $B$. subtilis in nutrient broth was $0.89 \mathrm{~g} / \mathrm{L}$, which was significantly greater than amounts in the RWP solutions $(P<0.05)$. However, increasing the percentage of lactose or protein in RWP did not significantly change surfactin production $(P<0.05)$.

\section{DISCUSSION}

Lactose-based media have not been commonly used as fermentation substrates for biopolymer production because most microorganisms, having deficiencies in lactose-hydrolyzing enzymes, cannot utilize lactose (Stauffer and Leeder, 1978; Racine et al., 1991; Flatt et al., 1992; Konicek et al., 1993; Dlamini and Peiris, 1997a,b). Bacillus subtilis, which possesses $\beta$-galactosidase (a lactose-hydrolyzing enzyme), can utilize lactose as a carbon source, with one study showing that 60 of 130 B. subtilis strains produced gluconate from a laboratory medium containing $2 \%$ lactose (Stauffer and Leeder, 1978). The increasing vegetative cell populations and decreasing $\mathrm{pH}$ values observed in this study support the fermentation of lactose by $B$. subtilis. Bacillus subtilis grew faster in 10\% RWP than in 15 or $20 \%$ RWP during $48 \mathrm{~h}$ of incubation at $30^{\circ} \mathrm{C}$. The initial amounts of lactose in 10, 15, and 20\% RWP 

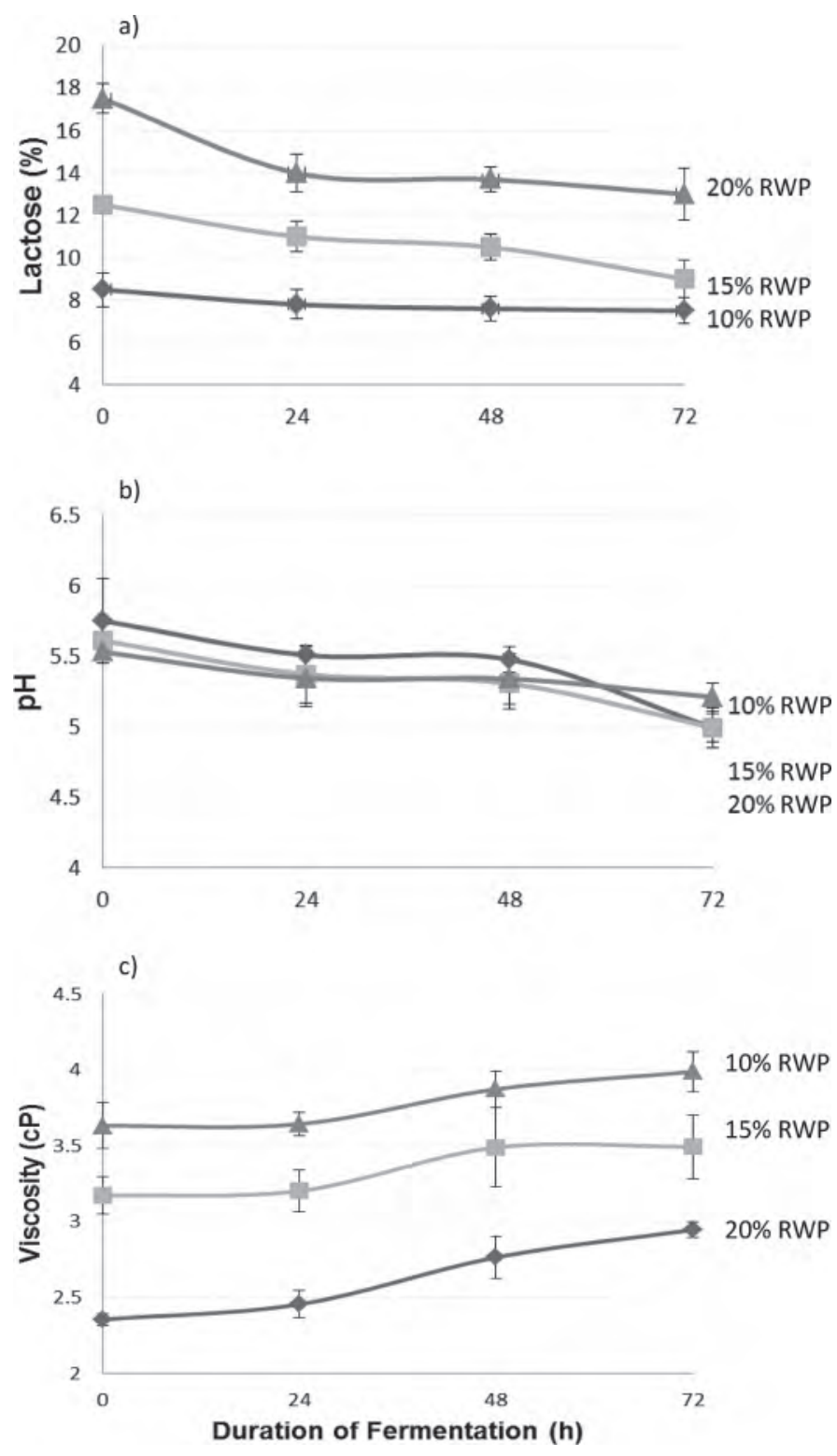

Figure 1. Mean \pm SD (a) lactose concentration (\%), (b) pH, and (c) viscosity of Bacillus subtilis cultured in 10,15 , or $20 \%$ rehydrated whey powder (RWP) during $72 \mathrm{~h}$ of fermentation $(\mathrm{n}=3)$.

were $8.5,12.5$, and $17.5 \%$, respectively. The presence of a higher lactose concentration (12.5 or $17.5 \%)$ in the medium might increase turgor in the cell, and a plateau effect might be reached to regulate the pressure in terms of carbohydrate utilization (Prescott et al., 2002).

Spore formation by $B$. subtilis was also examined in this study due to the close association with production of polysaccharides and antimicrobial agents. Hamon and Lazazzera (2001) found that a mutation in the spoA gene of $B$. subtilis that regulates sporulation suppressed production of a 3 -dimensional biofilm that was encased in an EPS matrix. However, no correlation was found between sporulation and polysaccharide production during the 72-h fermentation in the current study. The present study showed that sporulation began 48 $\mathrm{h}$ after the start of fermentation. Sporulation was most rapid in 20\% RWP that contained $17.5 \%$ lactose. However, the density of viable spores in 15 and $20 \%$ RWP decreased during the last $24 \mathrm{~h}$ of fermentation, likely because of suppression of vegetative growth from increased acidity.

On the understanding that increased lactose utilization will lead to a further increase in polysaccharide production (Schwartz and Bodie 1985), studies have been reported. For example, one strain of Pseudomonas elodea exhibited improved lactose utilization after serial transfer in enriched whey broth $(24 \mathrm{~h})$ followed by a lactose-rich $(4 \%, \mathrm{wt} / \mathrm{vol})$ medium (4 transfers in $11 \mathrm{~d})$ and whey (2 transfers in $4 \mathrm{~d}$; Dlamini and Peiris, 1997a). The improved strain exhibited 1.6 times as much intracellular $\beta$-galactosidase activity compared with the parent. For future studies, the lactose-utilization capacity of $B$. subtilis and polysaccharide production can be improved in the same way.

Colonies on solid media or in highly viscous liquid media produce EPS (Gugliandolo et al., 2003). Viscosity of RWP fermented by B. subtilis during $72 \mathrm{~h}$ also increased due to EPS production (Mitsuda et al., 1981). One particular polysaccharide produced by B. subtilis contains an amino sugar different from D-glucosamine and N-galactosamine, the usual amino sugar components of complex polysaccharides. This compound, which comprises between 1 and $2 \%$ of the total polysaccharide or about 0.1 to $0.2 \%$ of the bacterial cell dry weight, has been obtained in a pure crystalline state. Bacillus subtilis NCIM 2063 was examined by Borgio et al. (2009) for its EPS-producing ability in a basal salts solution, minimal salts medium, nitrogen-free medium, chemically defined medium, milk medium, and sewage from different areas. The highest EPS production (206 $\mathrm{mg} / \mathrm{L}$ ) by $B$. subtilis was observed in nitrogen-free medium after $7 \mathrm{~d}$ of incubation at $37^{\circ} \mathrm{C}$.

Surfactin has been characterized as a cyclic lipopeptide containing a carboxylic acid (3-hydroxy-13-methyl tetradecanoic acid) and 7 amino acids (Kakinuma et al., 1969a,b,c; Stein, 2005). The peptide is glutamic acid (N-bonded to the carboxylate of the fatty acid)L-leucine-D-leucine-L-valine-L-aspartic acid-D-leucineL-leucine (bonded to the 3-hydroxyl function). In the current study, 0.18 to $0.29 \mathrm{~g} / \mathrm{L}$ of surfactin was produced by $B$. subtilis using lactose and whey proteins as carbon source in RWP solutions. Similarly, when Abushadyi et al. (2005) used lactose as a carbon source, $0.25 \mathrm{~g} / \mathrm{L}$ of surfactin was produced by B. subtilis. In the current study, surfactin production was increased by 
Table 3. Concentrations of polysaccharide and surfactin produced by Bacillus subtilis in 10, 15, or $20 \%$ rehydrated whey protein (RWP) and RWP containing different ratios of lactose and protein during $72 \mathrm{~h}$ of fermentation at $30^{\circ} \mathrm{C}^{1}$

\begin{tabular}{lcc}
\hline Medium & Polysaccharide $(\mathrm{mg} / \mathrm{L})$ & Surfactin $(\mathrm{g} / \mathrm{L})$ \\
\hline RWP (\%, wt/vol) & & \\
10 & $513.6 \pm 12^{\mathrm{a}}$ & $0.23 \pm 11^{\mathrm{a}}$ \\
15 & $613.5 \pm 09^{\mathrm{a}}$ & $0.18 \pm 10^{\mathrm{a}}$ \\
20 & $768.3 \pm 15^{\mathrm{ab}}$ & $0.24 \pm 20^{\mathrm{a}}$ \\
Adjusted RWP (lactose/protein; \%, wt/vol) & $740.8 \pm 24^{\mathrm{ab}}$ & $0.16 \pm 9^{\mathrm{a}}$ \\
$10.0 / 0.5$ & $749.7 \pm 19^{\mathrm{ab}}$ & $0.30 \pm 12^{\mathrm{a}}$ \\
$7.5 / 0.5$ & $734.9 \pm 12^{\mathrm{ab}}$ & $0.22 \pm 8^{\mathrm{a}}$ \\
$5.0 / 0.5$ & $740.7 \pm 20^{\mathrm{ab}}$ & $0.25 \pm 7^{\mathrm{a}}$ \\
$2.5 / 0.5$ & & \\
Adjusted RWP (protein/lactose; \%, wt/vol) & $730.5 \pm 11^{\mathrm{ab}}$ & $0.19 \pm 10^{\mathrm{a}}$ \\
$1.5 / 2.5$ & $723.9 \pm 08^{\mathrm{ab}}$ & $0.20 \pm 13^{\mathrm{a}}$ \\
$1.0 / 2.5$ & $767.2 \pm 16^{\mathrm{ab}}$ & $0.29 \pm 18^{\mathrm{a}}$ \\
$0.5 / 2.5$ & $770.1 \pm 14^{\mathrm{ab}}$ & $0.89 \pm 13^{\mathrm{b}}$ \\
\hline Nutrient broth &
\end{tabular}

$\overline{\mathrm{a}, \mathrm{b}}$ Different lowercase letters within a column are significantly different $(P<0.05)$.

${ }^{1}$ Values are mean $\pm \mathrm{SD}(\mathrm{n}=3)$.

using nutrient broth $(0.5 \%$ peptone, $0.5 \%$ beef extract, $0.5 \%$ yeast extract) as the medium. However, when $B$. subtilis was grown in a nutrient broth medium for 24 $\mathrm{h}$, surfactin production was only about $0.1 \mathrm{~g} / \mathrm{l}$ (Arima et al., 1968).

Other studies revealed that antibiotic production by Bacillus species is variable, being influenced by changes in $\mathrm{pH}$ and the nutritional properties of the medium (Cooper et al., 1981; Chatterjee et al., 1992; Marahiel, 1992; Leifert et al., 1995; Stein, 2005). In this study, the low $\mathrm{pH}(5.5-5.7)$ and lack of glucose could have suppressed surfactin production. Abushadyi et al. (2005) reported optimum surfactin production $(2.25-3 \mathrm{~g} / \mathrm{L})$ by B. subtilis at $\mathrm{pH} 6.5$ and 7 in a medium containing 40 $\mathrm{g} / \mathrm{L}$ glucose $4.5 \mathrm{~g} / \mathrm{L} \mathrm{NH}_{4} \mathrm{NO}_{3}, 40 \mathrm{mg} / \mathrm{L} \mathrm{MnSO}_{4}$, and 6 $\mathrm{mM} \mathrm{FeSO}$, with surfactin production further improved by the addition of iron or manganese salts.

\section{CONCLUSIONS}

In conclusion, B. subtilis ATCC 6633 was able to grow in RWP using lactose as a carbon source. At the end of the 3-d fermentation process in RWP, polysaccharides and low amounts of surfactin were produced. Future studies should focus on optimizing the various parameters for surfactin and polysaccharide production by $B$. subtilis, including the $\mathrm{pH}$ or nutritional content of the medium.

\section{ACKNOWLEDGMENTS}

The authors thank Elliot T. Ryser (Michigan State University, East Lansing) for his critical review of this article. We also thank Milkon Sut Urunleri (Sakarya, Turkey) for providing the whey powder sample. Part of this work was supported by Sakarya University Scientific Research Projects Fund.

\section{REFERENCES}

Abushadyi, H. M., A. S. Bashandyi, N. H. Azizi, and H. M. M. Ibrahim. 2005. Molecular characterization of Bacillus subtilis surfactin producing strain and the factors affecting its production. Int. J Agric. Biol. 7:337-344.

Arima, K., A. Kakinuma, and G. Tamura. 1968. Surfactin, a crystalline peptide lipid surfactant produced by Bacillus subtilis: Isolation, characterization and its inhibition of fibrin clot formation. Biochem. Biophys. Res. Commun. 31:488-494.

Borgio, J. F., B. J. Bency, S. Ramesh, and M. Amuthan. 2009. Exopolysaccharide production by Bacillus subtilis NCIM 2063, Pseudomonas aeruginosa NCIM 2862 and Streptococcus mutans MTCC 1943 using batch culture in different media. Afr. J. Biotechnol. 9:5454-5457.

Chatterjee, S., D. K. Chatterjee, R. H. Jani, J. Blumbach, B. N. Ganguli, N. Klesel, M. Limbert, and G. Seibert. 1992. Mersacidin, a new antibiotic from Bacillus. In vitro and in vivo antibacterial activity. J. Antibiot. (Tokyo) 45:839-845.

Cooper, D. G., C. R. Macdonald, S. J. B. Duff, and N. Kosaric. 1981. Enhanced production of surfactin from Bacillus subtilis by continuous product removal and metal cation additions. Appl. Environ. Microbiol. 42:408-412.

de Brouwer, J. F. C., K. Wolfstein, and L. J. Stal. 2002. Physical characterization and dynamics of different fractions of extracellular polysaccharides in an axenic culture of a benthic diatom. Eur. J. Phycol. 37:37-44.

Desai, J. D., and I. M. Banat. 1997. Microbial production of surfactants and their commercial potential. Microbiol. Mol. Biol. Rev. 61:47-64.

Dlamini, A. M., and P. S. Peiris. 1997a. Production of exopolysaccharide by Pseudomonas sp. ATCC 31461 (Pseudomonas elodea) using whey as fermentation substrate. Appl. Microbiol. Biotechnol. $47: 52-57$.

Dlamini, A. M., and P. S. Peiris. 1997b. Biopolymer production by a Klebsiella oxytoca isolate using whey as fermentation substrate. Biotechnol. Lett. 19:127-130.

Feijoo, G., M. T. Moreira, E. Roca, and J. M. Lema. 1999. Use of cheese whey as a substrate to produce manganese peroxidase by Bjerkandera sp. BOS55. J. Ind. Microbiol. Biotechnol. 23:86-90.

Flatt, J. H., T.A. Cooper, J. M. Gonzalez, D. E. Dogger, E. N. Lightfoot, and D. C. Cameron. 1992. An anionic galactomannan poly- 
saccharide gum from newly isolated bacterium. II. Fermentation kinetics and lactose transport. Biotechnol. Prog. 8:335-339.

Gugliandolo, C., T. L. Maugeri, D. Cacamo, and E. Stackebrandt. 2003. Bacillus aeolius sp. nov., a novel thermophilic, holophilic marine Bacillus species from Eolian Islands (Italy). Syst. Appl. Microbiol. 26:172-176.

Gulsun, M., and A. Sahan. 1992. Peynir altı Suyunun ozellikleri. Gida (Gida Teknoloji Dernegi) 13:12-14.

Halkman, A. K., and M. Akcelik. 2000. Gıdaların Mikrobiyolojik Analizi 1. Temel İlkeler. Pages 203-228 in Gida Mikrobiyolojisi ve Uygulamaları. Genişletilmiş. 2nd ed. Ank. Üniv. Ziraat Fakültesi Gıda Mühendisliği Bölümü Yayını. Sim Matbaacılık Ltd. Şti., Ankara, Turkey.

Hamon, M. A., and B. A. Lazazzera. 2001. The sporulation transcription factor Spo0A is required for biofilm development in Bacillus subtilis. Mol. Microbiol. 42:1199-1209.

Hanson, R. S., and J. A. Phillips. 1981. Chemical composition. Pages 333-334 in Manual of Methods for General Bacteriology, P. Gerhardt, P. G. E. Murray, R. N. Costilow, E. W. Nester, W. A. Wood, N. R. Krieg, and G. B. Phillips, ed. American Society for Microbiology, Washington, DC.

Heerklotz, H., and J. Seelig. 2001. Detergent-like action of the antibiotic peptide surfactin on lipid membranes. Biophys. J. 81:15471554 .

Horton, B. S. 1993. Whey processing and utilisation. Bull. Int. Dairy Fed. 279:46-49.

Kahyaoglu, M., and V. Konar. 2006. Biosurfactant ramnolipit production by Pseudomonas aeruginosa using waste of sugar industry. Sci. Eng. J. Furat Univ. 18:493-498.

Kakinuma, A., M. Hori, M. Isono, G. Tamura, and K. Arima. 1969a. Determination of amino acid sequence in surfactin, a crystalline peptidelipid surfactant produced by Bacillus subtilis. Agric. Biol. Chem. 33:971-972.

Kakinuma, A., M. Hori, H. Sugino, I. Yoshida, M. Isono, G. Tamura, and K. Arima. 1969b. Determination of the location of lactone ring in surfactin. Agric. Biol. Chem. 33:1523-1524.

Kakinuma, A., H. Sugino, M. Isono, G. Tamura, and K. Arima. 1969c. Determination of fatty acid in surfactin and elucidation of the total structure of surfactin. Agric. Biol. Chem. 33:973-976.

Konicek, J., J. Lasik, and H. Safar. 1993. Production of exopolysaccharide by a new mutant strain of Achromobacter delicatulus using whey fermentation. Folia Microbiol. (Praha) 38:68-70.

Lee, S. Y., A. P. J. Middelberg, and Y. K. Lee. 1997. Poly (3-hydroxybutyrate) production from whey using recombinant Escherichia coli. Biotechnol. Lett. 19:1033-1035.
Leifert, C., H. Li, S. Hampson, S. Workman, D. Sigee, H. A. S. Epton, and A. Harbour. 1995. Antibiotic production and biocontrol activity by Bacillus subtilis CL27 and Bacillus pumilus CL45. J. Appl. Bacteriol. 78:97-108.

Marahiel, M. A. 1992. Molekular biologie und regulation mechanismen der antibiotika produktion in Bacillus. Naturwissenschaften $79: 202-212$.

Mitsuda, S., N. Miyata, T. Hirota, and T. Kikuchi. 1981. High viscosity polysaccharide produced by Bacillus polymyxa. Hakkokogaku Kaishi J. Soc. Ferment. Technol. 59:303-309.

Perez, C. C. Suarez, and G. R. Castra. 1992. Production of antimicrobials by Bacillus subtilis MIR 15. J. Biotechnol. 26:331-336.

Prescott, L. M., J. Harley, and D. A. Klein. 2002. Solutes and water activity. Pages 121-122 in Microbiology. 5th ed. McGraw Hill, New York, NY.

Racine, M., J. Dumont, C. P. Champagne, and A. Morin. 1991. Production and characterisation of the polysaccharide from Propionibacterium acidi- propionici on whey-based media. J. Appl. Bacteriol. 71:233-238.

Rech, R., C. F. Cassini, A. Secchi, and M. A. Z. Ayub. 1999. Utilization of protein-hydrolyzed cheese whey for production of $\beta$-galactosidase by Kluyveromyces marxianus. J. Ind. Microbiol. Biotechnol. 23:91-96.

SAS Institute. 1990. SAS/STAT User's Guide. Release 8.0. SAS Institute Inc., Cary, NC.

Schwartz, R. D., and E. Bodie. 1985. Production of high viscosity whey broths by lactose-utilizing Xanthomonas campestris strain. Appl. Environ. Microbiol. 50:1483-1485.

Stauffer, K. R., and J. G. Leeder. 1978. Extracellular microbial polysaccharide production by fermentation on whey or hydrolyzed whey. J. Food Sci. 43:756-758.

Stein, T. 2005. Bacillus subtilis antibiotics: Structures, syntheses and specific functions. Mol. Microbiol. 56:845-857.

Stephens, A. M. 1995. Bacterial polysaccharide. Pages 341-377 in Food Polysaccharides and Their Applications. 2nd ed. A. M. Stephens, ed. Marcel Dekker, New York, NY.

Wingender, J., T. R. Neu, and H. C. Flemming. 1999. What are bacterial extracellular polymeric substances. Pages 1-15 in Microbial Extracellular Polymeric Substances. J. Wingender, T. R. Neu, and H. C. Flemming, ed. Springer-Verlag, Heidelberg, Germany.

Yagci, S., A. Altan, F. Gogus, and M. Maskan. 2006. Gida atıklarının alternatif kullanım alanları. Turkish 9th Food Congress. Gaziantep Universitesi, Bolu, Turkey. 